\title{
A novel G21R mutation of the GJB2 gene causes autosomal dominant non-syndromic congenital deafness in a Cuban family
}

\author{
Raquel Rabionet ${ }^{1}$, Estela Morales-Peralta ${ }^{2}$, Núria López-Bigas ${ }^{1}$, Maria Lourdes Arbonés ${ }^{1}$ \\ and Xavier Estivill ${ }^{1}$ \\ ${ }^{1}$ Center for Genomic Regulation, Genes and Disease Program, Barcelona, Spain. \\ ${ }^{2}$ National Center of Medical Genetics, Havana, Cuba.
}

\begin{abstract}
Deafness is a complex disorder affecting $1 / 1000$ infants. In developed countries, more than $50 \%$ of deafness cases are thought to have a genetic cause. At least 40 loci for dominant non-syndromic deafness and another 30 for recessive non-syndromic deafness have been described. Mutations in the GJB2 gene are the cause of an important number of cases of non-syndromic recessive deafness but are not as common in non-syndromic dominant deafness cases. We describe here a new dominant mutation (G21R) in the GJB2 gene which causes deafness and has been identified in a three generation Cuban family with dominant non-syndromic congenital sensorineural profound deafness.
\end{abstract}

Key words: connexin 26, GJB2, DFNA3, hearing impairment.

Received: July 11, 2005; Accepted: December 14, 2005.

Deafness is a frequent disorder that affects about $1 / 1000$ newborns, and up to $4 \%$ of people younger than 45 years old (Nadol 1993). In developed countries, more than $50 \%$ of congenital deafness is thought to have a genetic etiology. Approximately $80 \%$ of these cases are recessively inherited and 15\% dominantly inherited (Cohen and Gorlin 1995).

More than 60 different mutations of the GJB2 gene have been described as causing recessive deafness in several populations (www.crg.es/deafness). In various populations the DFNB1 gene has been shown to be the most important recessive locus (Abe et al., 2000; Estivill et al., 1998; Sobe et al., 1999), with the DFNB1 gene 35delG mutation being the most frequent mutation of this gene in European populations (Gasparini et al., 2000). Although mutations implicated in dominantly inherited hearing impairment are not as common as those implicated in recessively inherited hearing impairment, a few DFNB1 mutations have been related to dominantly inherited hearing impairment, both non-syndromic [W44C (Denoyelle, et al., 1998), R184Q (Hamelmann et al., 2001), C202F (Morle et al., 2000) and R143Q (Loffler et al., 2001)] and syndromic with accompanying skin disease [G12R (Richard et al.,

Send correspondence to Raquel Rabionet. Center for Genomic Regulation, Passeig Marítim, 9-4508003 Barcelona, Spain. E-mail: kelly.rabionet@crg.es.
2002), delE42 (Rouan et al., 2001), G59A (Heathcote et al., 2000), D66H (Maestrini et al., 1999) and R75W (Richard et al., 1998)]. The identification of additional dominant GJB2 mutations might help in understanding the relationship between this gene and disease phenotypes. We have identified a new GJB2 mutation, G21R, which is responsible for a dominant non-syndromic hearing impairment phenotype segregating in a Cuban family.

We studied a Cuban family in which five individuals from three generations were affected with pre-lingual hearing impairment. Information on the progression of hearing impairment was obtained by interview. All affected members in this family presented congenital non-progressive sensorineural profound deafness. Audiometric studies were obtained for individuals III-3 and III-4 and showed profound hearing impairment at higher frequencies and a milder degree of hearing loss at lower frequencies. Environmental causes (e.g. infectious diseases, ototoxic drugs) for the hearing impairment in this family were excluded by interview.

Peripheral blood was obtained from five affected individuals and two non-affected relatives and DNA was extracted according to standard protocols. Samples for other members of the family were not obtained because they either could not be contacted or declined participation in the study. This study was approved by the Medical Ethics Committee of the Oncological Research Institute and in- 
formed consent was obtained from each participating member of the family or their legal guardian. Screening for mutations in the GJB2 coding region was performed using single-strand conformation polymorphism (SSCP) analysis as previously described (Rabionet et al., 2000), followed by the sequencing of abnormal banding patterns on an ABI 377 automated sequencer with ABI BigDye Terminators. A single $\mathrm{G}$ to A mutation was identified at position 61 leading to the substitution of a glycine residue at GJB2 position 21 to an arginine residue (the G21R mutation). The G21R mutation segregates with the deafness phenotype as indicated by the fact that it was present in all the affected family members investigated but absent in their non-affected relatives (Figure 1A). The G21R mutation has not previously been described in affected or control samples from other populations that have been investigated for GJB2 mutations, indicating that it is a rare substitution. In order to rule out a possible case of 'pseudo-dominant' inheritance, the samples were also tested for the presence of the two GJB6 deletions, del(GJB6-d13s1854) (del Castillo et al., 2005) and del(GJB6-D13S1830) (del Castillo et al., 2002), using the polymerase chain reaction (PCR) described elsewhere (del Castillo et al., 2005; del Castillo et al., 2002). The results showed that both deletions were absent, indicating that $\mathrm{G} 21 \mathrm{R}$ is a dominant mutation.

Only 15 out of the more than 100 GJB2 mutations so far identified cause dominantly inherited hearing impairment. Syndromic deafness, accompanied by skin disease has been reported to be caused by ten of these mutations [G12R, S17F and D50N (Richard et al., 2002), delE42 (Rouan et al., 2001), N54K (Richard et al., 2004), G59A

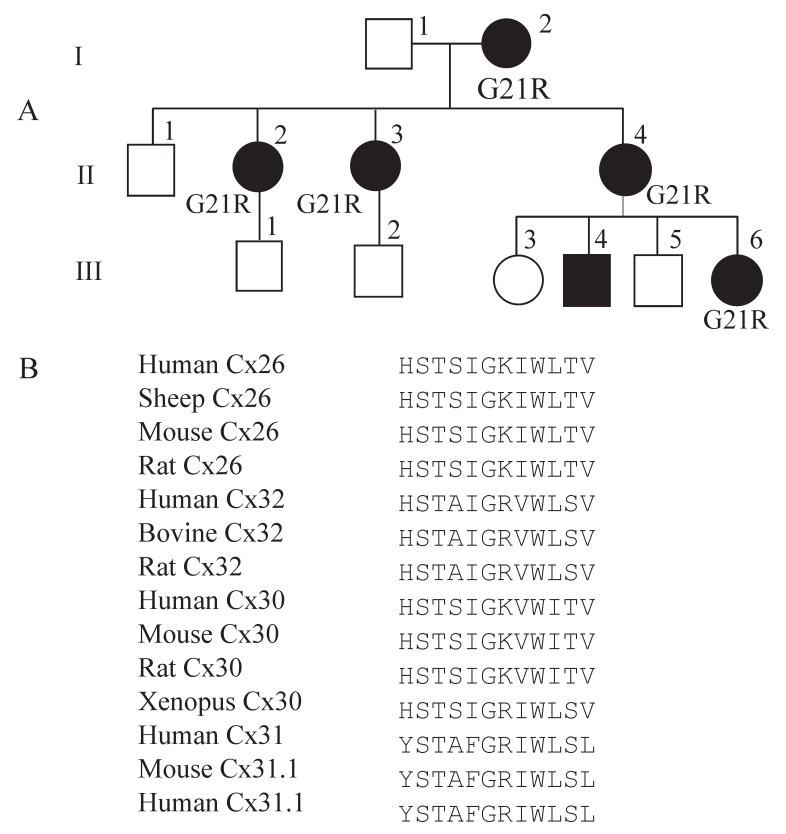

Figure 1 - A: Pedigree of the family carrying the GJB2 G21R mutation. The DNA for individuals with no genotype was not available. B: Comparison of the conservation of position 21 and surrounding amino acids in different connexins and in different species.
(Heathcote et al., 2000), D66H (Maestrini et al., 1999), R75Q (Uyguner et al., 2002), R75W (Richard et al., 1998), and $\mathrm{G} 130 \mathrm{~V}($ Snoeckx et al., 2005)]. The other reported dominant mutations in the GJB2 gene [W44C (Denoyelle et al., 1998), C202F (Morle et al., 2000), R143Q (Loffler et al., 2001), D179N (Primignani et al., 2003) and R184Q (Hamelmann et al., 2001)] and the G21R mutation cause non-syndromic deafness. Most of the mutations causing syndromic deafness lie in the connexin 26 first extracellular domain (Figure 2). G21R, instead, is located in the first intracellular domain, which has been proposed to be involved in voltage gating polarity (Bruzzone et al., 1996). The glycine at position 21 is a highly conserved amino acid, both between species and beta-connexins (Figure 1B). The non-conservative substitution of the small and neutral glycine for the bulkier and charged amino acid arginine could cause the resulting channel to be non-functional without preventing the formation of the channel itself. On the other hand, dominant mutations affecting the first extracellular domain probably interfere with hemichannel coupling.

The deafness phenotype observed in this family, congenital sensorineural profound deafness, is very similar to that described by Denoyelle et al. (1998) in several individuals carrying the GJB2 gene W44C mutation which is also related to dominant non-syndromic hearing impairment. These patients also showed profound loss at high frequencies and moderate hearing impairment at lower frequencies.

Although GJB2 dominant mutations are less common than recessive mutations, analysis of the GJB2 gene should be considered in diagnostic tests for both syndromic and non-syndromic dominantly inherited deafness. Functional studies on this and other GJB2 dominant mutations should allow comparison of the amino acid changes that lead to syndromic and non-syndromic deafness (Richard et al., 2002; Rouan et al., 2001) and should provide a better understanding of the molecular mechanisms underlying this disorder.

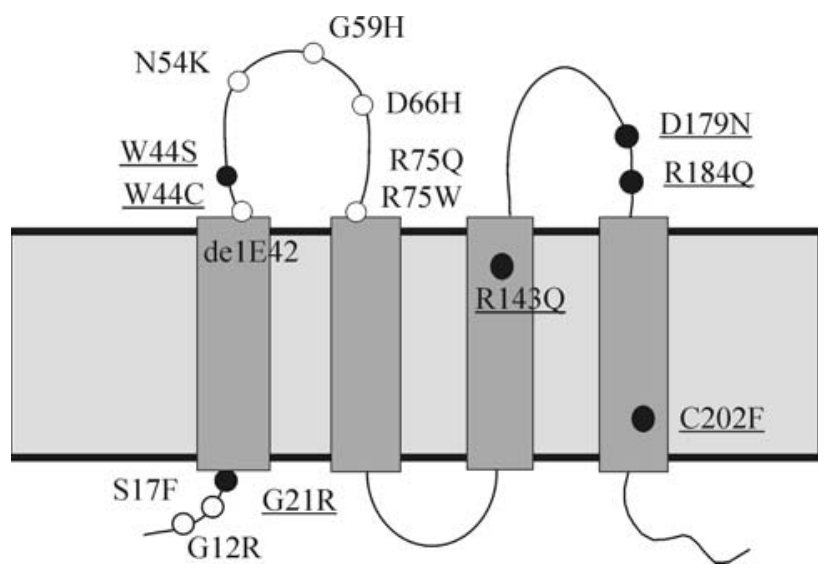

Figure 2 - Dominant mutations in the connexin 26 protein. Non-syndromic mutations are underlined and are represented by dark circles while syndromic mutations are represented by white circles. 


\section{Acknowledgments}

We thank the family for their cooperation. RR and NLB were supported by a BEFI grant from the FISS (98/9207 and 00/9379). This work was supported by La Marató TV3 (993610) and FIS-ISCIII (G03/203). NLB is supported by the Human Frontiers Science Program.

\section{References}

Abe S, Usami S, Shinkawa H, Kelley PM and Kimberling WJ (2000) Prevalent connexin 26 gene (GJB2) mutations in Japanese. J Med Genet 37:41-3.

Bruzzone R, White TW and Goodenough DA (1996) The cellular Internet: On-line with connexins. Bioessays 18:709-18.

Cohen MM and Gorlin RJ (1995) Epidemiology, etiology and genetic patterns. In: Gorlin RJ, Toriello HV and Cohen MM (eds) Hereditary Hearing Loss and its Syndromes. Oxford University Press, Oxford, pp 9-21.

del Castillo FJ, Rodriguez-Ballesteros M, Alvarez A, Hutchin T, Leonardi E, de Oliveira CA, Azaiez H, Brownstein Z, Avenarius MR, Marlin S, Pandya A, Shahin H, Siemering KR, Weil D, Wuyts W, Aguirre LA, Martin Y, MorenoPelayo MA, Villamar M, Avraham KB, Dahl HH, Kanaan M, Nance WE, Petit C, Smith RJ, Van Camp G, Sartorato EL, Murgia A, Moreno F and del Castillo I (2005) A novel deletion involving the connexin-30 gene, del(GJB6$\mathrm{d} 13 \mathrm{~s} 1854$ ), found in trans with mutations in the GJB2 gene (connexin-26) in subjects with DFNB1 non-syndromic hearing impairment. J Med Genet 42:588-94.

del Castillo I, Villamar M, Moreno-Pelayo MA, del Castillo FJ, Alvarez A, Telleria D, Menendez I and Moreno F (2002) A deletion involving the connexin 30 gene in nonsyndromic hearing impairment. N Engl J Med 346:243-9.

Denoyelle F, Lina-Granade G, Plauchu H, Bruzzone R, Chaib H, Levi-Acobas F, Weil D and Petit C (1998) Connexin 26 gene linked to a dominant deafness. Nature 393:319-20.

Estivill X, Fortina P, Surrey S, Rabionet R, Melchionda S, D’Agruma L, Mansfield E, Rappaport E, Govea N, Mila M, Zelante L and Gasparini P (1998) Connexin-26 mutations in sporadic and inherited sensorineural deafness. Lancet 351:394-8.

Gasparini P, Rabionet R, Barbujani G, Melchionda S, Petersen M, Brondum-Nielsen K, Metspalu A, Oitmaa E, Pisano M, Fortina P, Zelante L and Estivill X (2000) High carrier frequency of the $35 \mathrm{delG}$ deafness mutation in European populations. Genetic Analysis Consortium of GJB2 35delG. Eur J Hum Genet 8:19-23.

Hamelmann C, Amedofu GK, Albrecht K, Muntau B, Gelhaus A, Brobby GW and Horstmann RD (2001) Pattern of connexin 26 (GJB2) mutations causing sensorineural hearing impairment in Ghana. Hum Mutat 18:84-5.

Heathcote K, Syrris P, Carter ND and Patton MA (2000) A connexin 26 mutation causes a syndrome of sensorineural hearing loss and palmoplantar hyperkeratosis (MIM 148350). J Med Genet 37:50-1.
Loffler J, Nekahm D, Hirst-Stadlmann A, Gunther B, Menzel HJ, Utermann G and Janecke AR (2001) Sensorineural hearing loss and the incidence of $\mathrm{Cx} 26$ mutations in Austria. Eur J Hum Genet 9:226-30.

Maestrini E, Korge BP, Ocana-Sierra J, Calzolari E, Cambiaghi S, Scudder PM, Hovnanian A, Monaco AP and Munro CS (1999) A missense mutation in connexin26, D66H, causes mutilating keratoderma with sensorineural deafness (Vohwinkel's syndrome) in three unrelated families. Hum Mol Genet 8:1237-43.

Morle L, Bozon M, Alloisio N, Latour P, Vandenberghe A, Plauchu H, Collet L, Edery P, Godet J and Lina-Granade G (2000) A novel C202F mutation in the connexin26 gene (GJB2) associated with autosomal dominant isolated hearing loss. J Med Genet 37:368-70.

Nadol JB (1993) Hearing Loss. N Engl J Med 329:1092-1102.

Primignani P, Castorina P, Sironi F, Curcio C, Ambrosetti U and Coviello DA (2003) A novel dominant missense mutation D1-79N-in the GJB2 gene (Connexin 26) associated with non-syndromic hearing loss. Clin Genet 63:516-21.

Rabionet R, Zelante L, Lopez-Bigas N, D'Agruma L, Melchionda S, Restagno G, Arbones ML, Gasparini P and Estivill X (2000) Molecular basis of childhood deafness resulting from mutations in the GJB2 (connexin 26) gene. Hum Genet 106:40-4.

Richard G, Brown N, Ishida-Yamamoto A and Krol A (2004) Expanding the phenotypic spectrum of $\mathrm{Cx} 26$ disorders: BartPumphrey syndrome is caused by a novel missense mutation in GJB2. J Invest Dermatol 123:856-63.

Richard G, Rouan F, Willoughby CE, Brown N, Chung P, Ryynanen M, Jabs EW, Bale SJ, DiGiovanna JJ, Uitto J and Russell L (2002) Missense mutations in GJB2 encoding connexin-26 cause the ectodermal dysplasia keratitisichthyosis-deafness syndrome. Am J Hum Genet 70:1341-8.

Richard G, White TW, Smith LE, Bailey RA, Compton JG, Paul DL and Bale SJ (1998) Functional defects of Cx26 resulting from a heterozygous missense mutation in a family with dominant deaf-mutism and palmoplantar keratoderma. Hum Genet 103:393-9.

Rouan F, White TW, Brown N, Taylor AM, Lucke TW, Paul DL, Munro CS, Uitto J, Hodgins MB and Richard G (2001) trans-dominant inhibition of connexin- 43 by mutant connexin-26: Implications for dominant connexin disorders affecting epidermal differentiation. J Cell Sci 114:2105-13.

Snoeckx RL, Hassan DM, Kamal NM, Van Den Bogaert K and Van Camp G (2005) Mutation analysis of the GJB2 (connexin 26) gene in Egypt. Hum Mutat 26:60-1.

Sobe T, Erlich P, Berry A, Korostichevsky M, Vreugde S, Avraham KB, Bonne-Tamir B and Shohat M (1999) High frequency of the deafness-associated $167 \mathrm{delT}$ mutation in the connexin 26 (GJB2) gene in Israeli Ashkenazim. Am J Med Genet 86:499-500.

Uyguner O, Tukel T, Baykal C, Eris H, Emiroglu M, Hafiz G, Ghanbari A, Baserer N, Yuksel-Apak M and Wollnik B (2002) The novel R75Q mutation in the GJB2 gene causes autosomal dominant hearing loss and palmoplantar keratoderma in a Turkish family. Clin Genet 62:306-9.

Editor: Angela M. Vianna-Morgante 